\title{
MODERATING EFFECTS OF GOVERNMENT ASSISTANCE \& TURNAROUND STRATEGIES: A RESEARCH ON PRIVATE MANUFACTURING COMPANIES
}

\author{
*Tengku Mohammad Chairal ABDULLAH \\ **Zolkafli HUSSIN \\ *University of North Sumatera \\ ***Northern University of Malaysia
}

\section{ABSTRACT}

There were many cases in corporate turnaround that had seen the influence of government assistance in influencing the process of recuperating ailing firms. However to what extent such assistance positively influenced the outcome of turnaround result are still lacking in the literature. The objective of this paper is to investigate the moderating effect of government assistance towards the improvement of business performance of turnaround companies. Analysis of logistic regression was used to investigate the effect of retrenchment and product-market refocusing strategy and the combination effect of government assistance as a moderator towards the improvement of business performance of turnaround firms. The sample consists of 135 exporter-manufacturing companies listed in the Exporter Directory of the Province of North Sumatra, Indonesia. The study found partial support in the moderating effects of government assistance and firm size and their influence in the relationship between strategy and successful turnaround. The study also found that Product-Market refocusing is one of the important strategies to be implemented during turnaround.

Keywords: Corporate Turnaround, Turnaround Strategies, Logistic Regression, Moderating Effect, Government Assistance

\section{INTRODUCTION}

The recent economic crisis of 2008, which swept many of major industrial nations, saw one major shift in government policies towards ailing businesses. The conviction held especially by liberal economy, which dictates that the government interference should be limited in the business world, has been changed dramatically by the act of giving financial assistance in the effort to rescue ailing businesses, especially big companies. Though as literature would later show that government assistance has been there in rescuing troubled companies, this recent recession is perhaps the only one after many decades whereby such assistance massively came in hundreds of billion dollars of rescue package. Before the economic crisis of 2008, government assistance though arguably to be quite limited, was present in many cases of turnaround companies. There were many cases in the literature of corporate turnaround that showed the government taking part in the resuscitation of ailing companies especially if the company was considered to be an important asset to the nation. However, to what extent such assistance truly helped in revitalizing turnaround companies were found to be quite scant in terms of statistical reference.

This paper focuses on the effect of government assistance as a confounding factor and its influence on turnaround strategies towards the improvement of business performance of turnaround companies. The effect of company size, which also suspected to have certain moderating effect on strategy and performance, also will be considered in the study as a control variable. This paper begins with discussions on the theoretical background underlying the selection of turnaround strategies. Then several turnaround strategies commonly adopted by troubled companies will be discussed along with cases of corporate turnaround in which government assistance were present. 
Several hypotheses were developed in regards to the predictor as well as moderating variable in the study, in which the theoretical framework were based upon. It will then proceed with the section on research design, in which detail explanation on sampling, data collection and analytical procedure will be discussed. The research findings, implication and limitation will be presented in the final section of the paper.

\section{LITERATURE REVIEW}

Literature of corporate turnaround have shown that certain strategies such as retrenchment, cost reduction or downsizing were among popular strategies adopted by these troubled firms. One of the reasons that these strategies were widely adopted by ailing business was perhaps better explained by survival-based theory. This theory argued that in order to survive, organization had to deploy strategies that should be focused on running very efficient operation and can respond rapidly to the ever-changing environment (see e.g. Lynch, 2003). However, in reality, not all of these troubled companies which adopted this kind of strategies managed to successfully turnaround. As Slatter (1984) argued, only one out of four troubled companies managed to successfully turnaround itself. The lack of explanation provided by survival-based theory, open up possibilities for other theory of strategic management to lend itself in explaining the behavior of turnaround companies. Contingency theory as one of the most influential theories applied in strategy and organizational studies (Hofer, 1975) and one of which is widely adopted in strategic management (Miner, 1984), is one of the proposed candidate. The suspected moderating effect of some undefined factors which influence the outcome of turnaround effort is well within the boundary of contingency theory to explain.

Literature in the field of corporate turnaround in regards to strategy has been quite well developed for the last three to four decades. Since the earliest publication on the subject by Schendel \& Patton (1976), literature has been well developed to argue that turnaround companies would resort to certain types of turnaround strategies, namely: debt restructuring, operating-turnaround strategy, strategicportfolio restructuring strategy, and product-market refocusing strategy (Hofer, 1980; Tvorik, Boissoneau \& Pearson, 1998; Slatter, 1984; Sudarsanam \& Lai, 2001; Chowdury, 2002; Chowdury \& Lang, 1996; Hambrick \& Schecter, 1983; O'Neill, 1986; Slatter \& Lovett, 1999, and others). Although different scholar provided different technical term to these strategies, and sometimes found conflicting results, these terms are basically presents more or less the same meaning.

Aside from strategy, there are other non-strategy factors which influence performance of turnaround companies, or somewhat influence strategy - performance relationship of turnaround companies. Different business practices between Western and Asian companies for example, were argued by Bruton, Ahlstrom \& Wan (2003) as giving different effect on the turnaround effort of Asian companies, which also supported from other fellow researchers (see for e.g. Fisher, Lee \& Johns, 2004; Bruton, Ahlstrom \& Wan, 2001). Therefore it would be quite interesting to seek out other differences which exist or being practiced by turnaround companies in other parts of the world, especially in South East Asia. For the purpose of this study, two strategy-related factors and two non -strategy related factors, which will be treated as confounding factor, will be examined in the effort to further explain their influence on the improvement of performance of turnaround companies.

\section{The Factor of Operational-Efficiency Strategies}

Early scholars in the field referred to this strategy as retrenchment strategy, which arguably is among the first sets of strategies to be implemented by troubled firms (Robbins \& Pearce, 1992; Hofer, 1980). Literature on the field of corporate turnaround has found considerable support in the role of operational-efficiency strategy in revitalizing ailing companies (Robbins \& Pearce II, 1992; Chowdury \& Lang, 1996; Bruton \& Rubanik, 1997; Tvorik, Boissoneau \& Pearson, 1998). However there were several other researchers who found conflicting results in this particular role of operational-efficiency strategy (Barker III \& Mone, 1994; Castrogiovanni \& Bruton, 2000; Arogyaswamy \& Yasai-Ardekani, 1997). This strategy which is usually implemented to address operational (inefficiency) problems of troubled companies was usually aimed to improve short-term performance focusing on operational measures in the effort to gain efficiency and improving margin 
by reducing direct cost and slimming overheads in line with volume (Tvorik, Boissoneau \& Pearson, 1998; Hofer, 1980; Slatter, 1984; Chowdury, 2002). This strategy usually involves taking actions to improve operational cash flow and restore profitability by pursuing strict cost and operating-asset reduction (Sudarsanam \& Lai, 2001).

Turnaround Company usually pursues cost reduction through retrenchment of workers, pay cuts, reducing cost of materials and also overheads, though the first two are the most commonly mentioned. Scholars found conflicting evidence in the role of cost reduction to improve business performance. Many scholars found significant role of cost reduction in turning around ailing companies (Robbins \& Pearce II, 1992; Chowdury \& Lang, 1996; Bruton \& Rubanik, 1997; Tvorik, Boissoneau \& Pearson, 1998), though some others found the role was a bit vague (Barker III \& Mone, 1994; Castrogiovanni \& Bruton, 2000; Fisher, Lee \& Johns, 2004). Arogyaswamy \& YasaiArdekani (1997) found that retrenchment of workforce and pay cuts were both done by successfully and non-successfully turnaround firms, whereby some firms even successfully turnaround without retrenching their workers. Bruton, Ahlstrom \& Wan (2001) also argued that the ability to retrench is somewhat limited in East Asia, although in their subsequent research in 2003 (Bruton, Ahlstrom \& Wan, 2003), they argued that in the case that retrenchment occurred, it did improved performance. In practice, the role of cost reduction in improving business performance is widely accepted by turnaround firms, such as the turnaround of IBM (Slatter \& Lovett, 1999).

Operating-asset reduction was also deemed to be one of the measures taken during turnaround (Slatter, 1984; Ganto \& Sulaiman, 2005). This action usually involves selling-off less than full capacity of operating units such as plant or machinery, selling-off idle assets such as warehouses, office building, vehicles, and even short-term assets such as inventory and receivables (Sudarsanam \& Lai, 2001; Barker III \& Mone, 1994; Chowdury \& Lang, 1996; Castrogiovanni \& Bruton, 2000; Bruton, Ahlstrom \& Wan, 2003; Fisher, Lee \& Johns, 2004).This action were usually adopted to provide fast cash in a badly-needed cash-flow situation experienced by many turnaround companies, while at the same time getting rid of unused surplus of assets, enhancing efficiency at the operational level and improving asset utilization. Based on these arguments, operational-efficiency strategy which aimed to improve short-term performance by gaining efficiency was argued to have a direct influence on performance of company seeking turnaround, which leads us to the first hypothesis.

H1: There is a positive relationship between operational-efficiency strategies and successful turnaround companies

\section{The Factor of Product-Market Refocusing}

The strategy of product-market refocusing, was categorized by early scholars of corporate turnaround as part of recovery strategies (Schendel et al., 1976), growth strategy (O'Neill, 1986), revenue-generating strategy (Slatter, 1984), or as part of entrepreneurial turnaround strategy (Hambrick \& Schecter, 1983). However, it was Slatter (1984) who first surfaced this strategy as one among its generic turnaround strategies and differentiated it with other recovery strategies, which include strategy of improved marketing, product-market changes and growth through acquisition. In his later writings with Lovett (Slatter \& Lovett, 1999), they combined these strategies under productmarket refocusing, which include addition/ deletion of product lines, addition/ deletion of customers, changes in sales mix, complete withdrawal from a market segment, and entering into a new productmarket segment. Product-market refocusing strategies were widely supported as the instrument of growth in the literature of corporate turnaround (Kow, 2004), especially as the decline deepens (Chowdury, 2002). Product-market refocusing strategy were also found to be quite a popular strategy being adopted by many troubled firms in Malaysia (Siti Maimon, 1999) and Indonesia (Ganto \& Sulaiman, 2005) especially after the financial crisis of 1998.

Product refocusing through new product development and deletion of unprofitable product lines were practiced among troubled companies. There were cases in which careful new product development managed to bring the company out of the crisis, such as Fiat for example (Edmondson, et al. 2002). Market refocusing also found considerable support in the literature of corporate 
turnaround, though Harker (2001) argued it was still quite limited. Some of the scholars even argued that there were several aspect of marketing which differentiate between failed and successful turnaround companies (Harker \& Harker, 1998), such as careful selection of potential market and close relationship with customers (Cunnington, 1996). Micron for example, a Russian microchip manufacturer, were one of many cases in which turnaround companies resorted to this kind of strategy to pull themselves out of trouble (Bruton \& Rubanik, 1997). Based on these discussions, the second hypothesis is postulated.

H2: There is a positive relationship between product-market refocusing strategy and successful turnaround companies

\section{The Factor of Government Assistance}

There is no doubt that government has major influences on corporate life. They influence corporate through taxes, regulations and even sometimes in terms of business policy. In the aspect of turnaround, government was found to be helpful in some cases of government-related turnaround effort such as in the case of Chrysler Corp (Chowdury, 2002). In the wake of 2008 economic crisis, cases like this was found to be quite common. Aside from giving help, in certain cases of turnaround, government was found to be the reason for corporate decline, such as through budget cuts (Rose, 2003), or through tight monetary policy which shrink the government spending.

The role that government took when they decided to give assistance in the turnaround process was also found to be quite diverse. Many cases of government assistance came in the form of financial backup, such as the turnaround of Rover (Whitehead, 1999). Another type of assistance came in some form of mutual fund, which will be used to facilitate the debt and financial difficulties experienced by these troubled companies (see for e.g. Wilks, 2002). This is the type of assistance which are being used by many Southeast Asian countries during the economic recession of 1998, and also recently being used by industrial nation which were being hit by recent crisis. And sometimes government also influenced the turnaround process by supervising the process itself, such as in the case of turnaround at Daewoo (Lee, 1999). Even in some cases, government influenced the market side of turnaround by giving government contracts, such as in the turnaround of AMS (Mullich, 1998). These discussions on the government influence, whether direct or indirect, arguably have some effect on the turnaround process, which lead us to the third hypothesis.

\section{H3: The factor of government assistance shall moderate the relationship between strategy and successful turnaround companies.}

\section{RESEARCH DESIGN}

Financially distressed firms are defined as companies who experienced a two-year of simultaneous decline in net income and Return on Asset (ROA) between the period of 2000 and 2005. These two measures of performance were previously used by Bruton, Oviatt \& White (1994), Castrogiovanni \& Bruton (2000) and Fisher, Lee \& Johns (2004) in their study. Successful Turnaround Company is defined as companies who experienced a stable increase of profit (net income) and ROA between 2005 and 2007. The sampling frame in this study consists of manufacturing companies listed in the Exporter Directory of North Sumatera Province. From the total of 281 manufacturing companies listed in the directory, 179 falls into financially-distressed category, in which only 135 were included in the study. From the total of 135 companies, 87 companies fall into the category of successful turnaround, while the other 48 is classified as non-turnaround. Data was collected from February August 2009 by personal interview, in which the respondents were asked to fill up the self administered questionnaire.

Question items which were developed to measure the variables were adapted from the items developed by Barker III \& Barr (2002). This study also develops additional question items to strengthen the measures of strategies and also to measure government assistance as new variable. Three managing directors who were involved in a workshop held by local government were invited to discuss and develop the additional question items. Then another eight managing directors who 
attended the same workshop were given the items to check its face validity in accordance to the technique developed by Zaichkowsky (1985) and Obermiller \& Spangenberger (1998). The results are the final question items which were distributed to the respondents during data collection period. Since the question item was developed in native language, the validity and reliability of the question items has to be re-check. Exploratory Factor Analysis which was used to check the convergent validity of the items produced satisfactory result except for one item from Cost Reduction and another one from Market Refocusing, which both produced communality below .5. These items were excluded from further analysis. Reliability test for each variable is also quite satisfying with the score of Cronbach's Alpha well above 7 (Hair, et.al., 2005).

Scholars have shown that firm size has been somewhat associated with successful turnaround (Bruton, Ahlstrom \& Wan, 2003; Bruton, Oviatt \& White, 1994). Firm size has also been research quite rigorously in the context of contingency approach (see e.g. Donaldson, 2001). Therefore it was considered to be quite important to investigate the effect of firm size in the study as control variable. However since the exact and reliable figure of total asset of companies in the study was difficult to obtain, the study will use the classification given by the local government as a measure of firm size. For the purpose of measuring the firm size, the companies in the study were divided into three categories: (1) Companies with asset less than Rp. 2 billion, (2) Companies with asset between Rp 2 to 10 billion, (3) Companies with asset more than Rp. 10 billion. Dummy coding was used in the analysis, in which group (1) was considered as the reference group.

\section{RESULTS AND DISCUSSIONS}

Test for linearity of the logit as suggested by Tabachnick \& Fiddel (2007) showed no serious violations of the assumptions. Test for multicollinearity among predictors also showed no serious violation of the assumption of collinearity, with VIF score below 3.6. The analyses of binary logistic regression were performed in number of steps. First, each bivariate association between Size, Operational Efficiency Strategy (OEF), Product-Market Refocusing Strategy (PMR) and Government Assistance (GA) as predictor variables and turnaround success as the DV were examined in Model 1. Then each moderating variable will be paired up with each predictor variable to check the improvement of the model. And finally interaction term will be introduced with each model to check for the significance of the interaction. Mean centering was applied to all predictor variables prior creating the interaction term.

Table 1 shows the bivariate relationship between each predictor variable and turnaround success. Product-Market refocusing strategy has the biggest effect in improving the odds of turnaround success (33 times more likely than non-turnaround), while government assistance also shows significant influence on the odd ratio of turnaround success. Although Size and OES does not produce significant results ( $p>.05)$, Hosmer \& Lemeshow (2000: 95) argued that any variable with $\mathrm{p}$ value less than .25 still can be considered as a candidate in multivariable model. Therefore Size and OES will still be considered in further analysis.

\section{Table 1. Results of Logistic Regression Analysis on Model 1.}

The result of logistic regression analysis involving higher order interaction term is shown on Table 2

\begin{tabular}{|c|c|c|c|c|c|c|c|c|c|c|c|}
\hline \multirow[t]{2}{*}{ Variable } & \multirow[t]{2}{*}{$-2 \mathrm{LL}$} & \multicolumn{3}{|c|}{ Omuibus Test } & \multirow[t]{2}{*}{ NR-2 } & \multirow[t]{2}{*}{ B } & \multirow[t]{2}{*}{ Wald } & \multirow[t]{2}{*}{ Sig. } & \multirow[t]{2}{*}{ OR } & \multirow[t]{2}{*}{ CI } & \multirow{2}{*}{$\begin{array}{l}\text { Prediction } \\
\text { Accuracy }\end{array}$} \\
\hline & & Chi-2 & df & Sig. & & & & & & & \\
\hline Constant Only & 175.721 & & & & & & & & & & 64.4 \\
\hline Size - 1 & 171.956 & 3.765 & 2 & 0.152 & 0.038 & 0.965 & 3.223 & 0.073 & 2.625 & $.915-7.529$ & 64.4 \\
\hline Size - 2 & & & & & & 0.228 & 0.275 & 0.6 & 1.256 & $.536-2.947$ & 64.4 \\
\hline OES & 173.743 & 1.978 & 1 & 0.16 & 0.02 & -0.653 & 1.928 & 0.165 & 0.52 & $.207-1.309$ & 64.4 \\
\hline PMR & 127.265 & 448.456 & 1 & $<.001$ & 0.414 & 3.519 & 30.16 & $<.001$ & 33.763 & $9.615-118.554$ & 74.1 \\
\hline GA & 156.2 & 19.521 & 1 & $<.001$ & 0.185 & 1.64 & 16.29 & $<.001$ & 5.157 & $2.325-11.439$ & 69.6 \\
\hline
\end{tabular}

below. The analysis involves comparing higher order interaction with lower order components of the higher order model to see whether the inclusion of single variable can significantly improve the model, which is in someway similar to hierarchical regression analysis. Hosmer \& Lemeshow (2000) argued that computation of moderating variable in logistic regression is always in the form of 
hierarchical analysis, in which significance of the interaction term should always be checked prior interpretation of the result.

\section{Test of Hypotheses}

Hypothesis 1: $\quad$ There is a positive relationship between operational-efficiency strategies and successful turnaround companies

Hypothesis 1(a): Firm size moderates the relationship between operational-efficiency strategies and turnaround success

Hypothesis 1(b): Government Assistance moderates the relationship between operational-efficiency strategies and turnaround success

A direct bivariate relationship between OES and turnaround success, which is reported at Table 1, shows that OES does not produce significant influence towards turnaround success (p: .165). The interaction between firm size and OES shown under Model 2 in Table 2, also shows that the effect carried by Size is not significant enough to have moderated the relationship between EOS and turnaround success. In this case, it is fair enough to say that the evidence does not warrant sufficient justification to reject H1(a). This finding is in agreement with the findings of some scholars in the literature which found insufficient support of this strategy positively influence turnaround success (Bruton, Ahlstrom \& Wan, 2001; Arogyaswamy \& Yasai-Ardekani, 1997). One of the logical explanation on this fact is perhaps this strategy was pursued by turnaround as well as non-turnaround companies.

Table 2. Results of Logistic Regression Analysis on Model 2 - Model 5

\begin{tabular}{|c|c|c|c|c|c|c|c|c|c|c|}
\hline \multirow[t]{2}{*}{ Variable } & \multirow[t]{2}{*}{$-2 \mathrm{LL}$} & \multicolumn{3}{|c|}{ Omuibus Test } & \multirow[t]{2}{*}{ NR-2 } & \multirow{2}{*}{$\begin{array}{l}\text { Prediction } \\
\text { Accuracy }\end{array}$} & \multicolumn{4}{|c|}{ Odds Ratio (CI) } \\
\hline & & Chi-2 & $d f$ & Sig. & & & Model 2 & Model 3 & Model 4 & Model 5 \\
\hline Constant Only & 175.721 & & & & & 64.4 & & & & \\
\hline Size - 1 & 171.956 & 3.765 & 2 & 0.152 & 0.038 & 64.4 & 1.699 & 0.418 & & \\
\hline Size - 2 & & & & & & 64.4 & 2.356 & 2.248 & & \\
\hline OES & 173.743 & 1.978 & 1 & 0.16 & 0.02 & 64.4 & & & & \\
\hline PMR & 127.265 & 448.456 & 1 & $<.001$ & 0.414 & 74.1 & & & & \\
\hline $\mathrm{GA}$ & 156.2 & 19.521 & 1 & $<.001$ & 0.185 & 69.6 & & & $11^{*}$ & 0.664 \\
\hline $\mathrm{OES}$ & 168.483 & 3.473 & 1 & 0.062 & 0.072 & 62.2 & 1.03 & & & \\
\hline OES (SIZE -1) & 167.256 & 1.227 & 2 & 0.541 & 0.083 & 63 & 0.266 & & & \\
\hline OES (SIZE -2) & & & & & & & 0.134 & & & \\
\hline PMR & 114.179 & 57.777 & 1 & $<.001$ & 0.503 & 81.5 & & 4.348 & & \\
\hline PMR (SIZE -1) & 104.88 & 9.299 & 2 & 0.01 & 0.561 & 83 & & $564.165^{*}$ & & \\
\hline PMR (SIZE -2) & & & & & & & & 7.299 & & \\
\hline OES & 146.935 & 9.265 & 1 & 0.002 & 0.264 & 74.1 & & & $0.001 *$ & \\
\hline $\mathrm{OES}(\mathrm{GA})$ & 141.687 & 5.248 & 1 & 0.022 & 0.306 & 73.3 & & & $16.05 *$ & \\
\hline PMR & 126.283 & 29.917 & $\overline{1}$ & $<, 001$ & 0.421 & 74.1 & & & & $71.97 *$ \\
\hline PMR (GA) & 124.89 & 1.393 & 1 & 0.238 & 0.431 & 74.8 & & & & 5.468 \\
\hline
\end{tabular}

The moderating effect of Government Assistance (GA) on OES and turnaround success, which is shown in Model 3 in Table 2, produced quite significant result. In the presence of GA, the influence of OES toward turnaround success has somewhat improved. The EOS' odd ratio of .001 is the conditioned coefficient which reflects the changes of OES when GA equals to zero. While the odd ratio of product term (16.05), shows the factor multiplier by which the multiplying factor of OES changes given a unit increase in GA. Therefore, there is enough evidence to argue that Government assistance did influence the relationship between OES and turnaround success (H1b is accepted).

Hypothesis 2: $\quad$ There is a positive relationship between product-market refocusing strategies and successful turnaround companies

Hypothesis 2(a): Firm size moderates the relationship between product-market refocusing strategies and turnaround success 
Hypothesis 2(b): Government Assistance moderates the relationship between product-market refocusing strategies and turnaround success

Result of logistic regression analysis presented in Table 1, shows that PMR is the single most important predictor in the model. When entered into the equation model, the variable single handedly improves the prediction of turnaround success to $74.1 \%$. With an odd ratio of 33.76 , the presence of this variable in turnaround improves the probability of achieving turnaround success by as much as 33 times. Therefore it can be argued that PMR has a direct influence on turnaround success, which in this case, hypothesis $\mathrm{H} 2$ is accepted.

The effect of firm size on the relationship between PMR and turnaround success is reported in Model 3 at Table2. The statistical result shows that Size somewhat moderate this relationship, especially in the case of large companies (Size-1). PMR (Size-1) odd ratio of 564, shows by what "times" the multiplying factor of PMR would have change in the case of one unit change of Size. This is particularly quite true for large companies, as they have lots of resources and access to many markets, which they can fully use to their extent in order to revitalize their company. Therefore, hypothesis H2(a) is accepted, stating that Size do moderate the relationship between PMR and turnaround success. These finding is also in support with the findings of other scholars in the subject (Bruton, Ahlstrom \& Wan, 2003; Bruton, Oviatt \& White, 1994).

The moderating effect of Government Assistance in the relationship between PMR and turnaround success seems quite weak to be supported. The result on Model 5 in Table 2, shows that the model is not significantly different from the lower order model, which means that the introduction of the product term into the model is not significant. This might explain that Government (at least in the sample of study) does not assist much in the product or marketing section of turnaround companies, though this argument is still debatable. The statistical finding of data analysis failed to support sufficient evidence to accept hypothesis 2(b).

\section{Conclusion}

This study has attempted to see the moderating effect of Government Assistance in the relationship between Strategies and Turnaround Success. Firm Size was also considered as control variable in the analysis. The result shows that PMR has a direct and strong influence on turnaround success. The moderating variable of size and government assistance in this study was found to be partially supported. Firm size was found to moderate the relationship between PMR and turnaround success, while Government assistance moderates the relationship between OES and turnaround success. As with other study using logistic regression, the application of the study findings outside the sample should be carefully considered since normality was not universally assumed in logistic regression. This study is considered to be a mere step in the much-undisclosed world of corporate turnaround, especially in the aspect of government assistance in revitalizing troubled companies. 


\section{REFERENCES}

Arogyaswamy, K \& Yasai Ardekani, M. (1997). Organizational turnaround: understanding the role of cutbacks, efficiency improvements and investment in technology. IEEE Transaction on Engineering Management, 44, pp.3-11

Barker, V. L. III., \& Barr, P. S. (2002). Linking top manager attributions to strategic reorientation in declining firms attempting turnarounds. Journal of Business Research, 55, 963-979

Barker, V. L. III., \& Mone, M. A. (1994). Retrenchment: Cause of turnaround or consequence of decline? Strategic Management Journal, 15 (5), pp.395-405

Bruton, G. D., Ahlstrom, D., \& Wan, J. C. C. (2001). Turnaround success of large and midsized Chinese owned firms: Evidence from Hong Kong and Thailand. Journal of World Business, 36 (2), pp.146-165.

Bruton, G. D., Ahlstrom, D., \& Wan, J. C. C. (2003). Turnaround in East Asian firms: Evidence from ethnic overseas Chinese communities. Strategic Management Journal, 24 (6), pp.519-540

Bruton, G. D., Oviatt, B. M., and White, M. A. (1994). Performance of acquisitions of distressed firms. The Academy of Management Journal, 37 (4), pp.972-989

Bruton, G. D., \& Rubanik, Y. T. (1997). Turnaround of high technology firms in Russia: The case of Micron. Academy of Management Executive, 11 (2), pp.68-79

Castrogiovanni, G. J., \& Bruton, G. D. (2000). Business turnaround processes following acquisitions: Reconsidering the role of retrenchment. Journal of Business Research, 48, pp.25-34

Chowdury, S. D. (2002). Turnarounds: A stage theory perspective. Canadian Journal of Administrative Science, 19 (3), pp.249-266.

Chowdury, S. D., \& Lang, J. R. (1996). Turnaround in small firms: An assessment of efficiency strategies, Journal of Business Research, 48, pp.169-178

Cunnington, B. (1996). The marketing learning identity. Journal of Consumer Marketing, 13 (5), pp.56-65

Donaldson, L. (2001). The contingency theory of organization. United Kingdom: SAGE Publication Inc.

Edmondson, G., Tierney, C., Fairlamb, D., Brady, D., Welch, D., \& Carlisle, K. (2002). Running on empty: Fiat Auto in dire straits. Business Week International, May $13^{\text {th }}$, pp.18.

Fisher, G., Lee, J., \& Johns, L. (2004). An exploratory study of company turnaround in Australia and Singapore following the Asia crisis. Asia Pacific Journal of Management, 21, pp.149-170

Ganto, J., \& Sulaiman, M. (2005). Turnaround strategies and firm performance in Indonesian manufacturing industry. Proceedings to the $2^{\text {nd }}$ International Conference of the Asian Academy of Applied Business, July $28^{\text {th }}-30^{\text {th }}$, Padang, Indonesia

Hair, J., Black, WC., Babin, BJ., Anderson, RE., \& Tatham, RE. (2006). Multivariate Data Analysis. Prentice Hall. $5^{\text {th }}$ ed.

Hambrick, D. C. \& Schecter, S. M. (1983). Turnaround strategies for mature industrial-product business units. Academy of Management Journal, 26 (2), pp.231-248

Harker, M., \& Harker, D. (1998). The role of strategic selling in the company turnaround process. Journal of Personal Selling and Sales Management, 18 (2), pp.55-67. 
Harker, M. (2001). Market manipulation: A necessary strategy in the company turnaround process?. Qualitative Market Research, 4 (4), pp.197-206

Hofer C.W. (1975). Toward a contingency theory of business strategy. Academy of Management Review, 18, pp.784-810

Hofer, C.W. (1980). Turnaround strategies. Journal of Business Strategy, 1, pp.19-31

Hosmer, DW., and Lemeshow, S. 2000. Applied Logistic Regression. John Wiley \& Sons, $2^{\text {nd }}$ ed.

Kow, G. (2004). Turning around business performance: Part II. Journal of Change Management, 4 (4), pp. 281

Lee, C. S. (1999). Battle of wills. Far Eastern Economic Review, Aug $26^{\text {th }}, 162$ (34)

Lynch, R. (2003). Corporate Strategy . Prentice Hall, $3^{\text {rd }}$ ed.

Miner, J. B. (1984). The validity and usefulness of theories in an emerging organizational science. Academy of management Review, 9, pp.296-306.

Mullich, J. (1998). AMS rebounds. Information Week. Oct $19^{\text {th }}$

Obermiller, C., \& Spangenberger, ER. 1998. Development of a scale to measure consumer skepticism toward advertising. Journal of Consumer Psychology, 7(2), pp.159-86

O'Neill, H. M. (1986). Turnaround and recovery: What strategy do you need?. Long Range Planning, 19 (1), pp. $80-88$

Robbins, K., \& Pearce, A. J., II. (1992). Turnaround: recovery and retrenchment. Strategic Management Journal, 13, pp.287-309

Rose, C. D. (2003). University of California San Diego Medical Centre names new Chief Executive. Knight Ridder Tribune Business News, Jan $25^{\text {th }}$

Schendel, D., \& Patton, G. R. (1976). Corporate stagnation and turnaround. Journal of Economic and Business, 28, pp. 236-241

Siti Maimon Hj. Kamso, W. R. (1999). Strategic management options in Malaysia financial crisis: Turning around companies. Proceedings to the $3^{\text {rd }}$ Asian Academy of Management Conference.

Slatter, S. (1984). Corporate recovery: Successful turnaround strategies and their implementation. Singapore: Penguin Books

Slatter, S., \& Lovett, D. (1999). Corporate turnaround: Managing companies in distress. England: Penguin Books

Sudarsanam, S., \& Lai, J. (2001). Corporate Financial Distress and Turnaround Strategies: an Empirical Analysis. British Journal of Management, 12, pp.183-199

Tabachnick, B.G., \& Fidell, L.S. (2007). Using Multivariate Statistic. 5th ed. Boston: Pearson Education

Tvorik, S. J., Boissoneau, R., \& Pearson, N. (1998). Performance Parameters as Indicators of Success and Predictors of Failure in Strategic Management. Journal of Professional Service Marketing, 17 (2), pp.41-67

Whitehead, Mark. (1999). Rover's Return. People Management. 18 (5). Sep $16^{\text {th }}$ 
Journal of Global Strategic Management | V. 4 | N. 1 | 2010-June | isma.info | 64-73 | DOI: 10.20460/JGSM.2010415840

Wilks, Neil. (2002). Winding Up to Winding Down. Professional Engineering, Dec $11^{\text {th }}$ Bury, St. Edmund

Zaichkowsky, JL. (1985). Measuring the involvement construct. Journal of Consumer Research, 12, pp.341-52 